\title{
Growth and reproduction of the mangrove crab Goniopsis cruentata (Latreille, 1803) (Crustacea: Decapoda: Grapsidae) in southeastern Brazil
}

\author{
CARLA R.G. REIS ${ }^{1}$, FABIANO G. TADDEI ${ }^{2}$ and VALTER J. COBO ${ }^{1}$ \\ ${ }^{1}$ Laboratório de Biologia Marinha, Instituto de Biociências, Universidade de \\ Taubaté/UNITAU, Avenida Tiradentes, 500, 12030-180 Taubaté, SP, Brasil \\ ${ }^{2}$ Centro de Estudos Superiores de Parintins, Universidade do Estado do Amazonas \\ (CESP/UEA), Estrada Odovaldo Novo, Km 1, 69, 69152-470 Parintins, AM, Brasil
}

Manuscript received on October 8, 2013; accepted for publication on July 8, 2014

\begin{abstract}
Goniopsis cruentata is a common semi-terrestrial crab in Brazilian mangroves and an important fishery resource for traditional communities in the northeastern Brazilian coast. Aiming to contribute to the knowledge about the species, this study evaluated the carapace width and weight growth curves, the relative growth of weight versus carapace width, and the temporal variation of gonadosomatic and hepatosomatic indices for the species. A total of 524 crabs were collected in a mangrove area of Ubatuba municipality, state of São Paulo. The growth-curves parameters and longevity $\left(\mathrm{t}_{\max }\right)$ were estimated for males $(\mathrm{CW} \infty=50.6 \mathrm{~mm}$, $\mathrm{WE}=56.4 \mathrm{~g}, \mathrm{k}=2.24, \mathrm{t}_{0}=0.003631502$ year $^{-1}, \mathrm{t}_{\max }=1.3$ years $)$ and females $(\mathrm{CW} \infty=50.7 \mathrm{~mm}, \mathrm{WE} \infty=58.8 \mathrm{~g}$, $\mathrm{k}=2.50, \mathrm{t}_{0}=0.003247209$ year $^{-1}, \mathrm{t}_{\max }=1.2$ years). The age at onset of sexual maturity was 0.23 years for both genders. The weight-growth model was isometric for the immature developmental stages and allometric negative for adults. The species exhibited a continuous reproduction, with breeding peaks in spring and summer months. The weight dynamics of gonads and hepatopancreas were not clearly related. The growth and reproductive patterns indicated that Goniopsis cruentata has a life-history that prioritizes reproduction instead of survival. The species exhibited some of the highest growth rates and lowest longevity estimates reported for brachyuran species in Brazil.
\end{abstract}

Key words: gonad development, growth curves, hepatopancreas, relative growth.

\section{INTRODUCTION}

The crab Goniopsis cruentata (Latreille, 1803) is a common semi-terrestrial species in Brazilian mangroves. Its geographical range includes the western Atlantic Ocean from Bermuda to Brazil, and the eastern Atlantic Ocean from Senegal to Angola (Melo 1996). The species is an important

Correspondence to: Valter José Cobo

E-mail:vjcobo@unitau.br fishery resource for traditional communities in the northeastern Brazilian coast (Santos and Botelho 2002, Moura and Coelho 2004). There are no reports of economic exploitation of $G$. cruentata in the southeastern Brazilian coast. However, the exploitation of the species might become attractive in the future with the increasing decline in populations of crabs of economic importance in these coast (see Dias Neto 2011), as observed 
in the northeastern coast of Brazil (see Botelho et al. 2004). Beyond its economic value, $G$. cruentata may also play an important role in the functioning of mangrove ecosystems, by acting as an engineer species (Lima-Gomes et al. 2011), probably affecting soil biogeochemistry, rates of decomposition, and nutrient cycling (see Werry and Lee 2005, Kristensen 2008).

Some studies evaluated biological aspects of G. cruentata in Brazil: Silva and Oshiro (2002a) investigated the species growth in captivity; Lira et al. (2012) evaluated the weight versus carapace width relationship and the condition factor; Cobo and Fransozo $(1998,2005)$ and Moura and Coelho (2004) studied its physiological sexual maturity; Cobo and Fransozo (2000, 2003), Silva and Oshiro (2002b), and Moura and Coelho (2003) investigated reproductive aspects such as fecundity and breeding period; Garcia and Silva (2006) described the species testis and vas deferens morphology, and spermatophore formation; Garcia and Silva (2009) described the sperm cell development; Souza and Silva (2009) described the morphology of the female reproductive system and the development of the germ cells; Fransozo et al. (1998) described the species first zoeal stage; Moura et al. (2000), Santos and Botelho (2002), and Botelho et al. (2004) provided information on population structure; Lima-Gomes et al. (2011) investigated its feeding behaviour; and Maciel and Alves (2009) analyzed the knowledge and practices of traditional gatherers on the species.

Because of the species ecological and economic importance, the present study aimed to contribute to the knowledge about G. cruentata, providing information regarding the growth and reproduction, through the study of carapace width and weight growth curves, relative growth of weight versus carapace width, and gonadosomatic and hepatosomatic indices. The growth curve study provides information on growth rate, the age at onset of sexual maturity, the maximum body size attained, and the maximum longevity. Studies that described growth curves for brachyuran species in Brazil include Branco and Masunari (1992) for Callinectes danae; Branco and Lunardon-Branco (1993) for Callinectes ornatus; Ivo et al. (1999), Vasconcelos et al. (1999), and Pinheiro et al. (2005) for Ucides cordatus; Branco et al. (2002) for Portunus spinimanus; Silva-Castiglioni et al. (2004) for Uca rapax; Pimenta et al. (2005) for Armases rubripes; Pinheiro and Taddei (2005a), Taddei and Herrera (2010), and Davanso et al. (2013) for Dilocarcinus pagei; Pinheiro and Hattori (2006) for Arenaeus cribrarius; Barcelos et al. (2007) for Chasmagnathus granulatus; Keunecke et al. (2007) for Hepatus pudibundus; and Ferreira and D'Incao (2008) for Callinectes sapidus. The weight dynamics of gonads and hepatopancreas show metabolic processes underlying the reproductive cycle (see e.g. López-Greco and Rodríguez 1999, Rosa and Nunes 2002, 2003), and the relationship between the weight and the carapace-width enables the conversion between these variables and provides the weight growth rate. The information provided in the present study is useful to studies of aquaculture viability and studies establishing management guidelines for exploitation of natural populations (see e.g. Mello 1973, Santos 1978, Valenti et al. 1987, Dias Neto 2011), so far not available for the species.

\section{MATERIALS AND METHODS}

\section{SAMPLING AND BIOMETRY}

Monthly collections from April 2007 through March 2008 were carried out in a mangrove area, $\left(23^{\circ} 29^{\prime} 24^{\prime \prime S}, 45^{\circ} 10^{\prime} 12^{\prime \prime} \mathrm{W}\right)$ located inland of Praia Dura in Ubatuba municipality, state of São Paulo, southeastern Brazil (Fig. 1). The crabs were handcaught at low tide by 4 people for $1 \mathrm{~h} / \mathrm{month}$ without the use of traps or baits, and kept frozen until laboratory analysis. For each crab, the following measurements were recorded: (1) the gender and 
the developmental stage: young male (YM), adult male (AM), young female (YF), prepubertal female (PPF), and adult female (AF), based on the external morphology of the abdomen as proposed by Cobo and Fransozo (1998) and the adherence of the abdomen to the sternum criteria as proposed by Haefner (1990); (2) the carapace width $(\mathrm{CW})$, measured with a vernier caliper $(0.1 \mathrm{~mm})$; (3) the total weight (WE), measured on a digital balance $(0.1 \mathrm{~g})$; and (4) the gonad $(\mathrm{GW})$ and the hepatopancreas (HW) weights for both males and females, measured on a semi-analytical balance $(0.001 \mathrm{~g})$. The monthly air-temperature recorded for the period were obtained from the Instituto Agronômico de Campinas (IAC) in Campinas municipality for Ubatuba station (available at http://www.ciiagro.sp.gov.br).

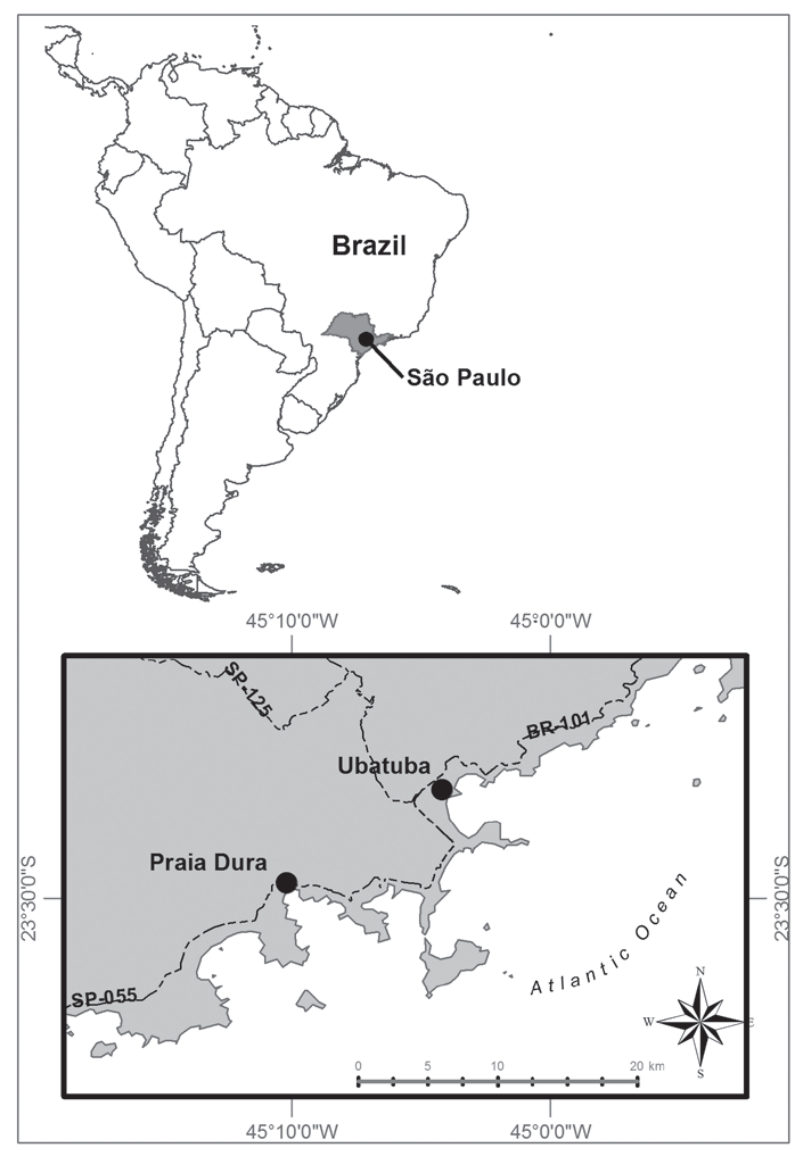

Figure 1 - Location of the Praia Dura in Ubatuba municipality, São Paulo, Brazil.

\section{DATA ANALYSIS}

The carapace width and the weight-growth curves were described for each gender according to the Bertalanffy model (1938): "CW $=\mathrm{CW} \infty\left[1-\mathrm{e}^{-\mathrm{k}(\mathrm{t}-\mathrm{t})}\right] "$

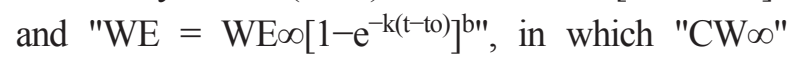
is the asymptotic carapace width, "WE $\infty$ " is the asymptotic weight, "e" is the basis of the Neperian logarithm, " $k$ " is a constant related to the species growth rate, " $t$ " is the age of the body size considered, " $\mathrm{t}_{\mathrm{o}}$ " is the age related to the body size at birth $\left(\mathrm{CW}_{\mathrm{o}}\right)$, and "b" is the allometric growth constant of the weight-carapace-width relationship. The main age groups for the period and the growthcurve parameters "CW $\infty$ " and "k" were estimated by the size-class distribution method (Fonteles-Filho 1987). The CW records were grouped monthly into 5 -mm size classes. The modes were identified by the Bhattacharya's method (1967) and confirmed by the NORMSEP routine (Pauly 1987) in the Elephan program of the FiSAT II (version 1.2.0) software package (Gayanilo et al. 2005). The " $\mathrm{t}_{\mathrm{o}}$ " value was estimated by substituting the zoea I mean carapace width $\left(\mathrm{CW}_{\mathrm{o}}\right)$ of Goniopsis cruentata, equal to $0.41 \mathrm{~mm}$ according to Fransozo et al. (1998), in the carapace-width growth equation. The "WE $\infty$ " was obtained by substituting the "CW $\infty$ " in the weight-carapace-width equation. Longevity was calculated according to Taylor (1958) through the equation $" t_{\max }=3 / \mathrm{k}+\mathrm{t}_{\mathrm{o}}$ ". The age at the onset of sexual maturity was estimated for each gender by substituting the size at physiological maturity proposed by Cobo and Fransozo (2005) for the same population of the present study, estimated as the size at which $50 \%$ of individuals attained gonadal maturity $($ males $=21.0 \mathrm{~mm} \mathrm{CW}$, females $=22.6 \mathrm{~mm}$ $\mathrm{CW}$ ), in the CW growth curves described.

For the relative growth analysis of weight versus carapace width, the WE and CW data were grouped according to gender and developmental stages. The data were subjected to a regression analysis with adjustment by the power function "WE $=\mathrm{a} \mathrm{CW}^{\mathrm{b}}$ ", in which "a" is the intercept 
and " $\mathrm{b}$ " is the allometric constant related to the weight-growth model: isometric $(b=3)$, allometric negative $(b<3)$, or allometric positive $(b>3)$. The determination coefficient $\left(\mathrm{r}^{2}\right)$ was used to evaluate the adjustment to the proposed model.

The gonadosomatic (GSI) and hepatosomatic (HSI) indices were estimated monthly for each sex through the equations "GSI = GW/WE x 100" and "HSI = HW/WE x 100" (Vazzoler 1981, 1996).

Except for the modal progression analysis of $\mathrm{CW}$, data of individuals with regenerating appendages were excluded from the analysis due to their influence on the individuals' WE.

\section{STATISTICAL ANALYSIS}

Normality was evaluated using the test of D'agostino (D'agostino 1970). Differences in the relative growth model between the genders and developmental stages were evaluated by comparing the angular (b) and linear (a) values using an ANCOVA (one-way) followed by the post hoc Tukey HSD test. The adjustment of " $b$ " values to an isometric weight-growth model was evaluated using a $t$-test. The temporal variation of GSI and HSI for each gender was assessed by the test of KruskalWallis followed by the post hoc Student-NewmanKeuls test. The relationship between variables was evaluated using the Spearman correlation analysis. Differences at the 0.05 level were considered as significant. All statistical analysis were performed according to Zar (2010).

\section{RESULTS}

A total of 524 crabs were obtained, being 26 young females, 68 prepubertal females, 196 adult females, 34 young males, and 200 adult males. Males exhibited mean body-sizes of $32.3 \pm 7.5$ $\mathrm{mm} \mathrm{CW}$ and $19.6 \pm 12.5 \mathrm{~g}$, ranging from 10.2 to $50.2 \mathrm{~mm} \mathrm{CW}$ and 0.6 to $61.7 \mathrm{~g}$. For females, mean body-sizes were $32.3 \pm 6.8 \mathrm{~mm} \mathrm{CW}$ and $17.2 \pm 8.8 \mathrm{~g}$, ranging from 13.3 to $50.1 \mathrm{~mm} \mathrm{CW}$ and 0.5 to $49.4 \mathrm{~g}$.
The $\mathrm{CW} \infty$ values estimated by the modal progression analysis (Fig. 2) were $50.6 \mathrm{~mm}$ for males and $50.7 \mathrm{~mm}$ for females. The constant "k" was 2.24 for males and 2.50 for females; and the parameter " $\mathrm{t}$ " was 0.003631502 years (about 1.3 days) for males, and 0.003247209 years (about 1.2 days) for females. The carapace-width growth can be described by the equation $\mathrm{CW}=50.6[1-\mathrm{e}$ $-2.24(\mathrm{t}+0.003631502)]$ for males, and by $\mathrm{CW}=50.7$ $\left[1-\mathrm{e}^{-2.50(\mathrm{t}+0.003247209)}\right]$ for females.

The $\mathrm{W} \infty$ values were $56.4 \mathrm{~g}$ for males and 58.8 $\mathrm{g}$ for females. The weight growth can be described by the equation $\mathrm{WE}=56.4\left[1-\mathrm{e}^{-2.24(\mathrm{t}+0.003631502)}\right]^{2.72}$ for males, and $\mathrm{WE}=58.8\left[1-\mathrm{e}^{-2.50(\mathrm{t}+0.003247209)}\right]^{2.93}$ for females. The longevity $\left(t_{\max }\right)$ estimates were 1.3 years for males and 1.2 for females. The bodysize estimates at the maximum age were $48.1 \mathrm{~mm}$ $\mathrm{CW}$ and $49.2 \mathrm{~g}$ for males and $48.2 \mathrm{~mm} \mathrm{CW}$ and $50.7 \mathrm{~g}$ for females.

Physiological maturity occurred at 0.23 years for both males and females.

Differences in the relative growth model were found between the genders $(F=19.54, d f$ $=1,469, p<0.0001)$ and developmental stages of males $(F=28.51, d f=1,206, p<0.0001)$ and females $(F=8.36, d f=2,260, p=0.0003$; Tukey HSD, $p<0.0001)$. The weight-growth model was isometric for the immature developmental stages and allometric negative for adults (Table I).

The GSI analysis revealed a continuous gonadal activity during the study period (Fig. 3). The testicular activity did not vary significantly throughout the period $(H=16.11, d f=11,167, p$ $=0.1371)$. In contrast, females showed higher ovarian activity from August through March $(H=60.30, d f=11,165, p<0.0001)$. The GSI of females was positively correlated to the mean air temperature $\left(r_{s}=0.35, d f=175, p<0.0001\right)$. The HSI of both males and females declined in June, remained low until January, and increased in February (Males: $H=69.24, d f=11,196, p$ $<0.0001$; Females: $H=72.93, d f=11,251, p<$ 


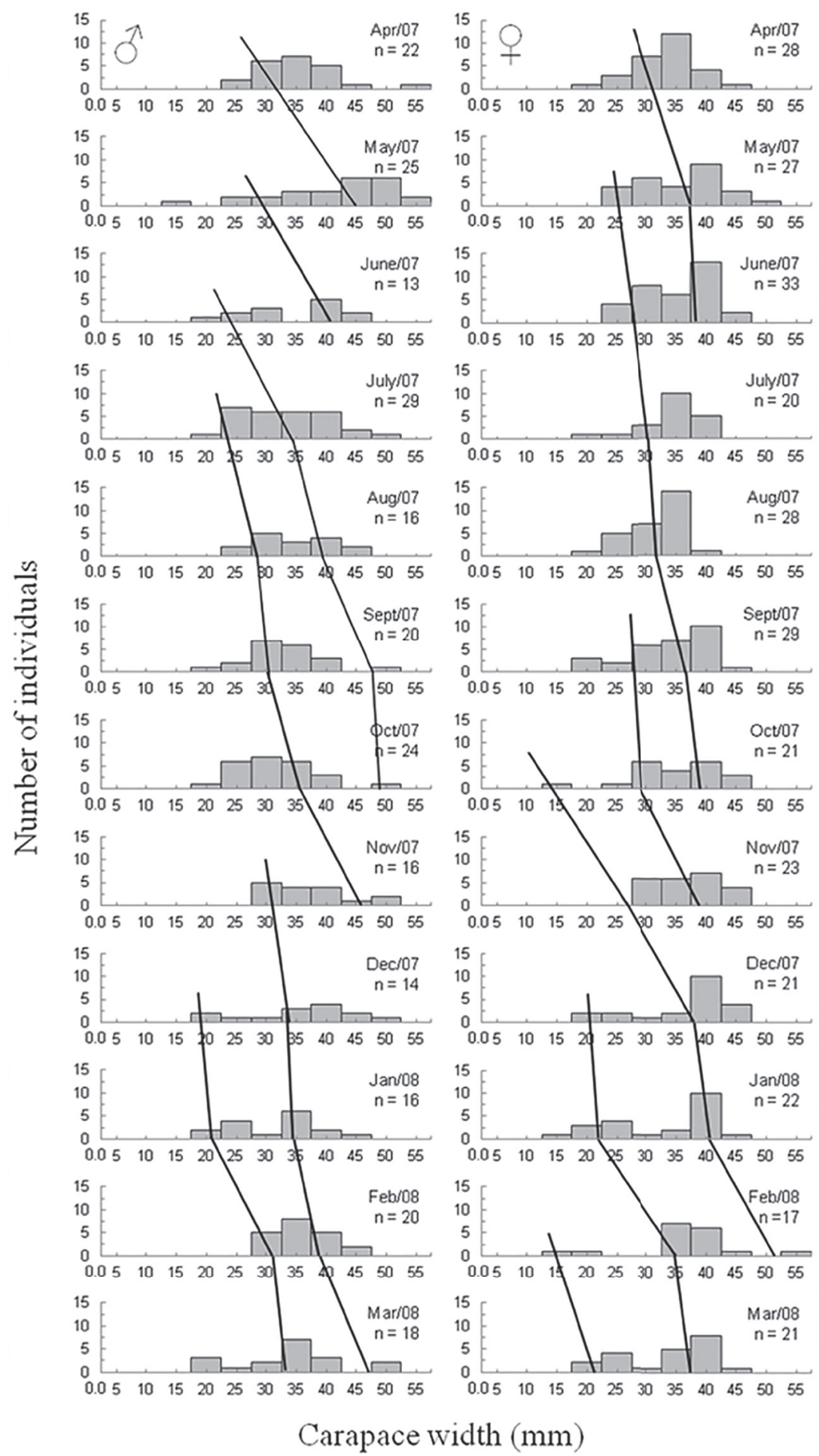

Figure 2 - Monthly distributions in carapace width size classes and age groups identified by modal progression analysis of Goniopsis cruentata from a mangrove area in Ubatuba municipality, São Paulo, Brazil, during the period of April 2007 to March 2008. 
TABLE I

Relative growth analysis of the total body weight (WE) versus the carapace width $(\mathrm{CW})$ of Goniopsis cruentata grouped by gender and developmental stages.

\begin{tabular}{ccccc}
\hline Group & $\boldsymbol{N}$ & Equation & $\boldsymbol{r}^{2}$ & $\boldsymbol{T}$ \\
\hline $\mathrm{YM}$ & 29 & $\mathrm{WE}=8 \times 10^{-4} \mathrm{CW}^{2.81}$ & 0.86 & 0.90 \\
$\mathrm{AM}$ & 179 & $\mathrm{WE}=5.9 \times 10^{-3} \mathrm{CW}^{2.31^{*}}$ & 0.69 & 6.05 \\
$\mathrm{TM}$ & 208 & $\mathrm{WE}=1.3 \times 10^{-3} \mathrm{CW}^{2.72^{*}}$ & 0.82 & 3.19 \\
$\mathrm{YF}$ & 26 & $\mathrm{WE}=6 \times 10^{-4} \mathrm{CW}^{2.92}$ & 0.68 & 0.21 \\
$\mathrm{PPF}$ & 60 & $\mathrm{WE}=1.3 \times 10^{-3} \mathrm{CW}^{2.70}$ & 0.81 & 1.78 \\
$\mathrm{AF}$ & 177 & $\mathrm{WE}=1.7 \times 10^{-3} \mathrm{CW}^{2.62^{*}}$ & 0.89 & 5.50 \\
$\mathrm{TF}$ & 263 & $\mathrm{WE}=6 \times 10^{-4} \mathrm{CW}^{2.93}$ & 0.94 & 1.66 \\
\hline
\end{tabular}

"YM"= young males, "AM"= adult males, "TM"= total males, "YF"= young females, "PPF"= prepubertal females, "AF" = adult females, "TF"= total females, " $N "$ indicates the sample size, $" r^{2}$ is the determination coefficient, " $t$ " indicates the value of $t$-test, and "*" indicates that the angular value was statistically different of $3(p<0.0001)$.

0.0001) (Fig. 3). The HSI of males was positively correlated to the GSI $\left(r_{s}=0.25, d f=177, p=\right.$ $0.0006)$. The HSI of females was not correlated to GSI $\left(r_{s}=0.08, d f=261, p=0.0804\right)$.

\section{DISCUSSION}

Sample sizes proved to be adequate to describe the species growth curves as all modes exhibited statistically significant separation indexes. The low number of juveniles collected due to biased sampling (very small crabs are harder to collect) is a common feature in studies with brachyuran species (see, e.g. Moura et al. 2000, Pinheiro et al. 2005, Pinheiro and Hattori 2006, Keunecke et al. 2007). However, this deficiency was counteracted by the growth rate and longevity estimates performed using FiSAT II.

Goniopsis cruentata exhibited high growth rates and low longevity compared to other brachyuran species in Brazil (Table II). Only Armases rubripes (Pimenta et al. 2005), Chasmagnathus granulatus
(Barcelos et al. 2007), and Hepatus pudibundus (Keunecke et al. 2007) were reported to exhibit growth rates as high as G. cruentata. None of the species listed in Table II were reported to exhibit longevity estimates as low as $G$. cruentata. Although most longevity estimates reported for brachyuran species in Brazil fall between 2 and 4 years, some authors had already reported probable annual cycles for brachyuran species indicated by modal progressions ending in approximately one year, like Taddei and Herrera (2010) and Davanso et al. (2013) reported for Dilocarcinus pagei. The species $G$. cruentata also exhibited continuous reproduction confirmed by GSI analysis, successive broods as indicated by the short length cohorts observed during the entire study period, and early sexual maturity at 0.23 years ( 2.8 months) compared to other brachyuran species in Brazil, which range from 5 months for Arenaeus cribarious (Pinheiro and Hattori 2006) to 3 years for Ucides cordatus (Pinheiro et al. 2005). Earlier, Cobo and Fransozo (2000) found a considerably high mean fecundity for this same population (about 57,000 eggs per brood). All these traits suggest that $G$. cruentata has a life-history that prioritizes reproduction instead of survival, wherein a fast growth provides selective advantages for both genders. Fast growing individuals attain sexual maturity at larger body sizes. For $G$. cruentata, larger females were found to produce a greater number of eggs per brood (Cobo and Fransozo 2000) while larger males probably defeat the smaller ones in competition for receptive females and get accepted more frequently by females, as observed for other brachyuran species (see Jaroensutasinee and Jaroensutasinee 2003, Brockerhoff and McLay 2005).

Females of $G$. cruentata exhibited a higher growth rate and were larger than same-aged males. This pattern is not commonly reported for Brachuyra, only Pinheiro and Taddei (2005a) and Taddei and Herrera (2010) found the same for the freshwater crab Dilocarcinus pagei. Females are more frequently 

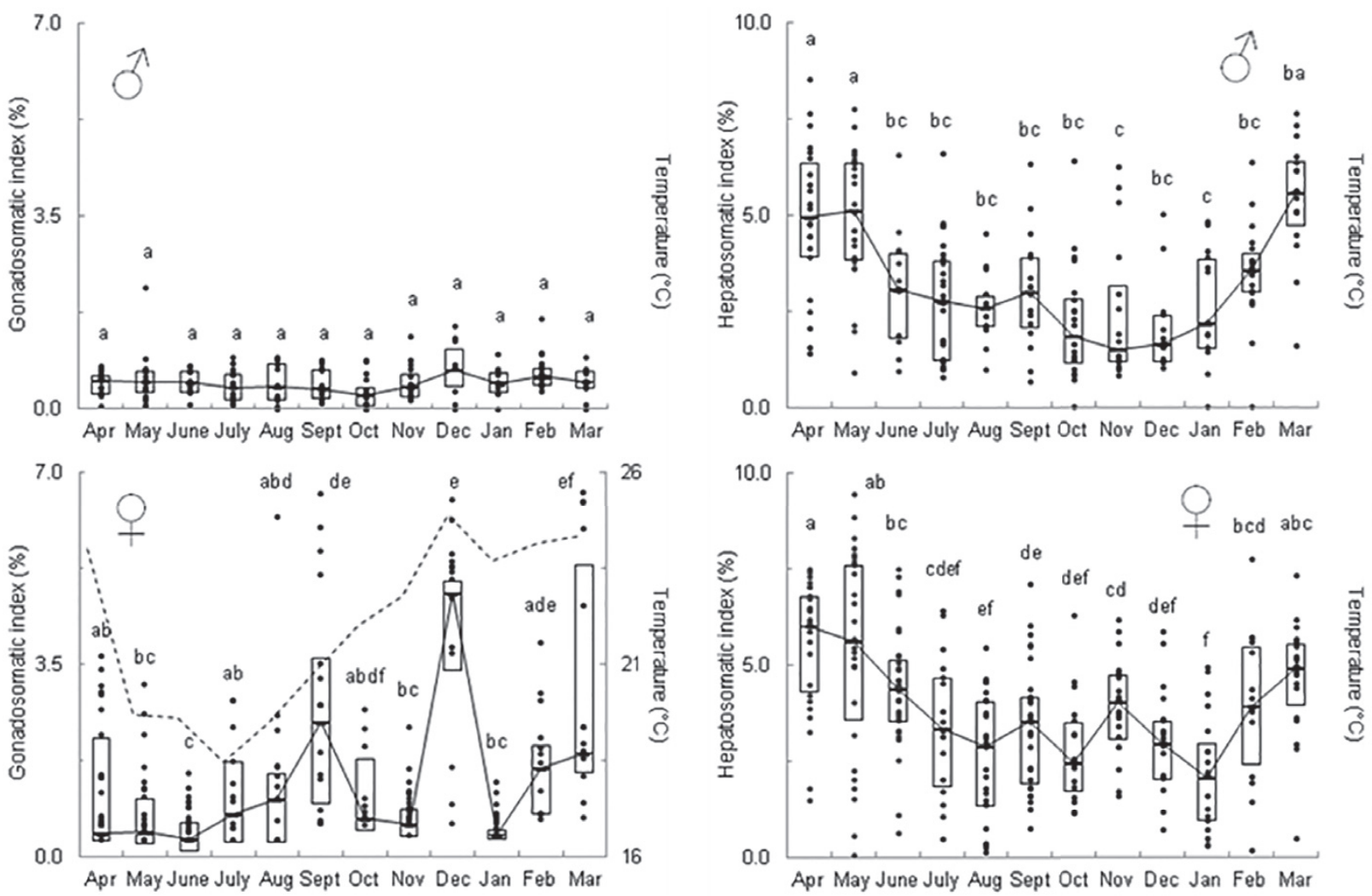

Figure 3 - Gonadosomatic (GSI) and hepatosomatic (HSI) indices of Goniopsis cruentata from a mangrove area in Ubatuba municipality, São Paulo, Brazil, during the period of April 2007 to March 2008. Median values and first and third quartiles are presented. Distinct letters reveal statistical difference between months $(\mathrm{p}<0.05)$. The number of individuals in each month ranged from 8 to 23 , with a mean of 15 . The mean air-temperature is indicated by the dashed line.

found to exhibit similar or lower growth rates (see Table II) and smaller body sizes than same-aged males as reported for Callinectes ornatus (Branco and Lunardon-Branco 1993), Portunus spinimanus (Branco et al. 2002), Arenaeus cribrarius (Pinheiro and Hattori 2006), and Chasmagnathus granulatus (Barcelos et al. 2007). Sexual dimorphism in size in which males are larger than females is considered an important reproductive strategy in Brachyura, specially for species whose females' sexual receptivity is associated with molting events. During and after copulation, males hold females providing protection against predators and other males until female's exoskeleton becomes calcified, ensuring paternity and reducing sperm competition. The larger body size of males compared to females allows an easier pair formation in such cases (Pinheiro and Fransozo 1999, Brockerhoff and McLay 2005, Pinheiro and Hattori 2006). For G. cruentata, females become sexually receptive during intermolt periods when the gonopore opercula become mobile (Hartnoll 1968) and males do not provide post-copulatory guarding (Schöne and Schöne 1963 apud Brockerhoff and McLay 2005, Schöne 1968). It seems that there are no strong selective pressures for $G$. cruentata males grow faster than females. In this context, fast growing females would have a selective advantage because they attain sexual maturity at larger $\mathrm{CW}$ sizes with a greater cephalothoracic space for gonad development and egg production, therefore improving reproductive effort (Pinheiro and Taddei 2005a, Taddei and Herrera 2010). 
TABLE II

Growth rate $(k)$ and longevity $\left(t_{\max }\right)$ estimated for brachyuran species in Brazil.

\begin{tabular}{lcccccc}
\hline Species & \multicolumn{2}{c}{$\mathbf{k}\left(\mathbf{y e a r}^{-1}\right)$} & $\mathbf{t}_{\max }$ (years) & Locality & Source \\
\cline { 2 - 5 } Uca rapax & $\mathrm{M}$ & $\mathrm{F}$ & $\mathrm{M}$ & $\mathrm{F}$ & & \\
Uca rapax & 0.16 & 0.15 & 3.9 & 4.3 & Ubatuba (SP) & 6 \\
Ucides cordatus & 0.21 & 0.16 & 4.4 & 4.9 & Ubatuba (SP) & 6 \\
Callinectes ornatus & 0.28 & 0.26 & 10.8 & 11.6 & Iguape (SP) & 8 \\
Portunus spinimanus & 0.52 & 0.66 & 3.0 & 3.0 & Matinhos (PR) & 2 \\
Callinectes danae & 0.61 & 0.59 & 1.8 & 1.8 & Penha (SC) & 5 \\
Dilocarcinus pagei & 0.70 & 0.66 & 3.5 & 3.5 & Florianópolis (SC) & 1 \\
Dilocarcinus pagei & 0.68 & 0.73 & 4.4 & 4.1 & Mendonça (SP) & 14 \\
Ucides cordatus & 0.97 & 1.41 & 2.4 & 2.7 & São José Rio Preto (SP) & 9 \\
Ucides cordatus & 1.12 & 0.90 & $2.7 *$ & $3.3 *$ & Curimatau River (RN) & 4 \\
Callinectes sapidus & 1.22 & 1.20 & $2.5 *$ & $2.5 *$ & Parnaíba River (PI) & 3 \\
Callinectes sapidus & 1.40 & 1.44 & 3.3 & 3.2 & Saco da Mangueira (RS) & 13 \\
Dilocarcinus pagei & 1.48 & 1.42 & 3.0 & 3.2 & Saco do Arraial (RS) & 13 \\
Arenaeus cribrarius & 1.78 & 1.67 & 2.6 & 2.8 & Icém (SP) & 15 \\
Goniopsis cruentata & 1.80 & 1.60 & 1.8 & 2.0 & Ubatuba (SP) & 10 \\
Chasmagnathus granulatus & 2.24 & 2.50 & 1.3 & 1.2 & Ubatuba (SP) & 16 \\
Armases rubripes & 2.4 & 2.6 & 2.0 & 2.0 & Tavares (RS) & 11 \\
Hepatus pudibundus & 2.48 & 3.03 & 1.8 & 1.8 & Lagoa dos Patos (RS) & 7 \\
\hline
\end{tabular}

"M" = males, "F" = females. * Data calculated from "k" and " $\mathrm{t}_{0}$ " values reported by authors, according to Taylor (1958); ** The study area extended from Paraty (RJ) to São Sebastião Island (SP). Source: ${ }^{1}$ Branco and Masunari (1992); ${ }^{2}$ Branco and Lunardon-Branco (1993); ${ }^{3}$ Ivo et al. (1999); ${ }^{4}$ Vasconcelos et al. (1999); ${ }^{5}$ Branco et al. (2002); ${ }^{6}$ Silva-Castiglioni et al. (2004); ${ }^{7}$ Pimenta et al. (2005); ${ }^{8}$ Pinheiro et al. (2005); ${ }^{9}$ Pinheiro and Taddei (2005a); ${ }^{10}$ Pinheiro and Hattori (2006); ${ }^{11}$ Barcelos et al. (2007);

${ }^{12}$ Keunecke et al. (2007); ${ }^{13}$ Ferreira and D'Incao (2008); ${ }^{14}$ Taddei and Herrera (2010); ${ }^{15}$ Davanso et al. (2013); and ${ }^{16}$ present study.

Silva and Oshiro (2002a) investigated the molt increment and intermolt period of $G$. cruentata in captivity collected in a mangrove area of Mangaratiba, state of Rio de Janeiro. These authors reported a continuous growth through successive molts and a similar mean number of molts (about 3 ) and molt increment (6.1\%) for males and females over the 1.25 years of study period, suggesting that both genders exhibited similar growth rates, in contrast to the findings of the present study. At the beginning of that study, individuals had a mean size of about $36 \mathrm{~mm} \mathrm{CW}$ and about $7 \%$ of them survived for an additional 1.25 years, which is the entire lifespan estimated for the species in the present study. According to the longevity estimates and CW growth curves described here, individuals exhibiting
$36 \mathrm{~mm} \mathrm{CW}$ would be about 0.5 years old and would live for an additional 0.7 to 0.8 years. As individuals attained similar CW sizes in both studies, the lower longevity exhibited by G. cruentata in the present study also implies in a higher growth rate compared to the population studied by Silva and Oshiro (2002a). Other authors also reported differences in absolute growth patterns for brachyuran species from different locations, even from close latitudes, which was mainly attributed to differences between habitats such as in primary productivity or sheltering (e.g. Silva-Castiglioni et al. 2004, Pinheiro et al. 2005, Ferreira and D'Incao 2008).

The relative growth study revealed that immature individuals of $G$. cruentata grew in carapace width and weight at the same proportion 
while adult individuals grew proportionally more in carapace width than in weight. Other authors reported changes in the weight-growth model through ontogeny for brachyuran species, including Mantelatto and Fransozo (1992) for Hepatus pudibundus, Pinheiro and Fransozo (1993) for Arenaeus cribarius, and Peiró et al. (2011) for Austinixa aidae. Mantelatto and Fransozo (1992) suggested that such changes occur as a result of hormonal processes associated with sexual maturity. As mentioned earlier, G. cruentata females exhibit a positive correlation between the carapace width size and the number of eggs produced (Cobo and Fransozo 2000), probably because larger females have a greater internal volume of the cephalothorax cavity available for gonad development (Hines 1982). Thus, the greater growth in carapace width after sexual maturity is achieved, may provide a greater reproductive effort for females. For G. cruentata males, the greater growth in carapace width with sexual maturity, may provide advantages in fights for receptive females. The allometric constants exhibited by adult males and females, which are within the lower range of allometric constants reported for brachyuran species in Brazil, ranging from 2.39 for Dilocarcinus pagei (Pinheiro and Taddei 2005b) to 5.00 for Austinixa aidae (Peiró et al. 2011). Araújo et al. (2012), suggested that the negative allometry exhibited by semi-terrestrial brachyuran species may be related to the branchial chambers development. Given the positive correlation between the carapace width size and the branchial chambers volume found in brachyuran species (Santos et al. 1985), a greater growth in carapace width may provide a higher surface area for branchiostegal lung development in the branchial chambers of G. cruentata.

The results of GSI analysis are in agreement with previous reports that $G$. cruentata has a continuous reproduction with breeding peaks in the warmest months of the year (e.g. Cobo and Fransozo 1998, 2003). The breeding period of brachyuran species in tropical and subtropical areas frequently follows a continuous pattern, probably due to the greater constancy of favorable conditions over the year compared to temperate zones, wherein crabs generally breed seasonally (Sastry 1983, Morgan and Christy 1995, Ramirez Llodra 2002, Litulo 2005). Breeding peaks are also frequently found for crabs in tropical and subtropical areas (e.g. Pillay and Nair 1971, 1973, Branco et al. 1992, Flores and Negreiros-Fransozo 1998, Leme 2002, 2006, Litulo 2005), probably as a result of successive broods (Sastry 1983). Like the seasonal breeding in temperate regions, breeding peaks in tropical and subtropical areas may have selective advantages because a larger amount of offspring are released under favorable abiotic conditions.

The GSI were not clearly related to HSI in $G$. cruentata. The synthesis of vitellogenin in decapods, which is the precursor of the common yolk protein stored during later phases of oogenesis, was suggested to occur in the ovary, in the hepatopancreas, from where vitellogenin would be transported through the hemolymph to developing oocytes, or in both organs (Tsukimura 2001). Several studies have supported the mobilization of resources from hepatopancreas to developing gonads in decapod crustaceans (e.g. Kyomo 1988, Pillay and Nair 1973, Haefner and Spaargaren 1993, Spaargaren and Haefner 1994, López-Greco and Rodríguez 1999) while a lower number of studies have found the opposite (e.g. Castille and Lawrence 1989, Cavalli et al. 2001, Rosa and Nunes 2002, 2003). The lack of a significant relationship between GSI and HSI for females, suggests that vitellogenin synthesis in Goniopsis cruentata might mainly occur in the ovary and be more dependent on resources from digestion than on hepatopancreas reserves. However, resources can be mobilized from hepatopancreas to developing gonads at the same time that hepatopancreas resources are restored by feeding (see Tuck et al. 
1997). In this case, the weight dynamics of these organs could not evidence the transference of resources. Further studies are necessary to reach a conclusion, mainly studies that evaluate the dynamics of lipids, proteins, and vitellogenin in the ovaries, hepatopancreas, and hemolymph of the species. More-conclusive studies are necessary to better understand the role of hepatopancreas weight dynamics for the species.

The growth and reproductive patterns observed in the present study enabled the authors to conclude that Goniopsis cruentata has a life-history that prioritizes reproduction instead of survival.

\section{ACKNOWLEDGMENTS}

The authors are thankful to UNITAU for their logistical support, to LaBMar/UNITAU and NEBECC members for their help in field collections, and to anonymous referees for improving the manuscript. This study was supported by the Conselho Nacional de Desenvolvimento Científico e Tecnológico (CNPq, grant number 103955/2007-0).

\section{RESUMO}

Goniopsis cruentata é um caranguejo semi-terrestre comum em manguezais brasileiros e um importante recurso pesqueiro para comunidades tradicionais no nordeste do Brasil. Com o objetivo de contribuir com o conhecimento sobre a espécie, o presente estudo avaliou as curvas de crescimento em largura de carapaça e em peso, o crescimento relativo do peso pela largura da carapaça e a variação temporal dos índices gonadossomático e hepatossomático para a espécie. Um total de 524 caranguejos foram coletados em área de manguezal no município de Ubatuba, estado de São Paulo. Os parâmetros das curvas de crescimento e a longevidade $\left(\mathrm{t}_{\max }\right)$ foram estimados para machos $(\mathrm{CW} \infty=50,6 \mathrm{~mm}$, $\mathrm{WE} \infty=56,4 \mathrm{~g}, \mathrm{k}=2,24, \mathrm{t}_{0}=0,003631502$ ano $^{-1}, \mathrm{t}_{\max }=1,3$ anos) e fêmeas $(\mathrm{CW} \infty=50,7 \mathrm{~mm}, \mathrm{WE} \infty=58,8 \mathrm{~g}, \mathrm{k}=2,50$, $\mathrm{t}_{0}=0,003247209$ ano $^{-1}, \mathrm{t}_{\max }=1,2$ anos). A idade no início da maturidade sexual foi de 0,23 anos para ambos os sexos. O modelo de crescimento em peso foi isométrico para indivíduos em estágios de desenvolvimento imaturos e alométrico negativo para adultos. A espécie exibiu reprodução contínua com picos reprodutivos nos meses de primavera e verão. A dinâmica de peso das gônadas e hepatopâncreas não estiveram claramente relacionadas. Os padrões de crescimento e reprodução indicaram que Goniopsis cruentata possui uma história de vida que prioriza a reprodução em detrimento da sobrevivência. A espécie exibiu algumas das maiores taxas de crescimento e menores estimativas de longevidade relatados para espécies de braquiúros no Brasil.

Palavras-chave: desenvolvimento gonadal, curvas de crescimento, hepatopancreas, crescimento relativo.

\section{REFERENCES}

ARAúJo MSLC, Silva-CASTIGLIONi D AND CoElHo PA. 2012. Width-weight relationship and condition factor of Ucides cordatus (Crustacea, Decapoda, Ucididae) at tropical mangroves of Northeast Brazil. Iheringia Sér Zool 102: 277-284.

Barcelos DF, Silva-Castiglioni D, BARUtot RA AND SANTOS S. 2007. Growth of Chasmagnathus granulatus (Crustacea, Decapoda, Grapsidae) at Lagoa do Peixe, state of Rio Grande do Sul, Brazil. Iheringia Sér Zool 97: 263-267.

BERTALANFFY VON L. 1938. A quantitative theory of organic growth. Hum Biol 10: 181-213.

BHATTACHARYA CG. 1967. A simple method of resolution of a distribution into Gaussian components. Biometrica 23: $115-135$

Botelho RO, ANDRAdE CER AND SANTOS MCF. 2004. Estudo da população de aratu-do-mangue, Goniopsis cruentata (Latreille, 1803) (Crustacea, Decapoda, Grapsidae) no estuário do rio Camaragibe (Alagoas - Brasil). Bol Téc Cient CEPENE 12.

BRANCO JO AND LUNARDON-BRANCO MJ. 1993. Crescimento e tamanho de primeira maturação em Callinectes ornatus Ordway, 1863 (Decapoda, Portunidae) da região de Matinhos, Paraná, Brasil. Arq Biol Tecnol 36: 497-503.

BRANCO JO, LUNARDON-BRANCO MJ AND SOUTO FX 2002. Estrutura populacional de Portunus spinimanus Latreille (Crustacea, Portunidae) na Armação do Itapocoroy, Penha, Santa Catarina, Brasil. Rev Bras Zool 19: 731-738.

Branco JO, LunARdon MJ, Ávila MG AND Miguez CF. 1992. Interação entre fator de condição e índice gonadossomático como indicadores do período de desova em Callinectes danae Smith (Crustacea, Portunidae) da Lagoa da Conceição, Florianópolis, Santa Catarina, Brasil. Rev Bras Zool 9: 175-180. 
BRANCO JO AND MASUNARI S. 1992. The growth of Callinectes danae Smith (Decapoda, Portunidae) from the Conceição lagoon, Florianópolis, Santa Catarina state, Brazil. Rev Bras Zool 9: 53-66.

BRockerhofF AM AND MCLAY CL. 2005. Comparative analysis of the mating strategies of grapsid crabs with special reference to the intertidal crabs Cyclograpsus lavauxi and Helice crassa (Decapoda: Grapsidae) from New Zeland. J Crust Biol 25: 507-520.

CASTILlE FL AND LAWRENCE AL. 1989. Relationship between maturation and biochemical composition of the gonads and digestive glands of the shrimps Penaeus aztecus and Penaeus setiferus (L.). J Crust Biol 9: 202-211.

CaValli RO, Tamtin M, LaVens P And Sorgeloos P. 2001. Variations in lipid classes and fatty acid content in tissues of wild Macrobrachium rosenbergii (de Man) females during maturation. Aquaculture 193: 311-324.

Cobo VJ And Fransozo A. 1998. Relative growth of Goniopsis cruentata (Crustacea, Brachyura, Grapsidae), on the Ubatuba region, São Paulo, Brazil. Iheringia Sér Zool 84: 21-28.

Cobo VJ And Fransozo A. 2000. Fecundity and reproduction period of the red mangrove crab Goniopsis cruentata (Brachyura, Grapsidae), São Paulo state, Brazil. In: Klein JC von V and Schram FR (Eds), The Biodiversity crisis and Crustacea, Rotterdam: A.A. Balkema Publishers, Rotterdam, Netherlands, p. 527-533.

CoBo VJ AND FrAnSOZO A. 2003. External factors determining breeding season in the red mangrove crab Goniopsis cruentata (Crustacea, Decapoda, Grapsidae), on the São Paulo State northern coast, Brazil. Rev Bras Zool 20: 213-217.

CoBo VJ AND FRAnsozo A. 2005. Physiological maturity and relationship of growth and reproduction in the red mangrove crab Goniopsis cruentata (Latreille) (Brachyura, Grapsidae) on the coast of São Paulo, Brazil. Rev Bras Zool 22: 219-223.

D'Agostino RB. 1970. Transformation to normality of the null distribution of g1. Biometrika. 57: 679-681.

Davanso TM, TAddei FG, Simões SM, Fransozo A AND CostA RC. 2013. Population dynamics of the freshwater crab Dilocarcinus pagei in tropical waters in southeastern Brazil. J Crust Biol 33: 235-243.

Dias Neto J. 2011. Proposta de plano nacional de gestão para o uso sustentável do caranguejo-uçá, do guaiamum e do siri-azul. Brasília: IBAMA, 156 p.

FERREIRA LS AND D'INCAO F. 2008. Growth of Callinectes sapidus (Crustacea, Decapoda, Portunidae) in the estuary of the Patos Lagoon, RS, Brazil. Iheringia Sér Zool 98: 70-77.

Flores AAV AND NEGREIROS-FrANSOZO ML. 1998. External factors determining seasonal breeding in a subtropical population of the shore crab Pachygrapsus transversus (Gibbes, 1850) (Brachyura, Grapsidae). Invert Reprod Develop 34: 149-155.

FONTELES-FILHO AA. 1987. Recursos pesqueiros, Biologia e Dinâmica Populacional. Fortaleza: Imprensa Oficial do Ceará, 296 p.
Fransozo A, Cuesta JA And Negreiros-Fransozo ML. 1998. The first zoea stage of two species of Grapsidae (Decapoda, Brachyura) and a key to such larvae from the brazilian coast. Crustaceana 71: 331-343.

GARCIA TM AND SILVA JRF. 2006. Testis and vas deferens morphology of the red-clawed mangrove tree crab (Goniopsis cruentata) (Latreille, 1803). Braz Arch Biol Technol 49: 339-345.

GARCIA TM AND SILVA JRF. 2009. Sperm cell development of the red-clawed mangrove-tree crab, Goniopsis cruentata Latreille, 1803 (Crustacea: Decapoda: Grapsidae). Arq Ciên Mar 42: 36-39.

Gayanilo Jr FC, SPARre P AND PAuly D. 2005. FAOICLARM stock assessment tools II (FiSAT II). Revised version. User's guide. FAO Computerized Information Series (Fisheries). No. 8, Revised version. Rome: FAO, $168 \mathrm{p}$.

HAEFNER Jr PA. 1990. Morphometry and size at maturity of Callinectes ornatus (Brachyura, Portunidae) in Bermuda. Bull Mar Sci 46: 274-286.

HAEFNER Jr PA AND SPAARGAREN DH. 1993. Interactions of ovary and hepatopancreas during the reproductive cycle of Cangron cangron (L.). I. Weight and volume relationships. J Crust Biol 13: 523-531.

HARTNOLL RG. 1968. Morphology of the genital ducts in female crabs. J Linn Soc Zool 47: 279-300.

HINES AH. 1982. Allometric constraints and variables of reproductive effort in brachyuran crabs. Mar Biol 69: 309-320.

IVo CTC, DiAs AF AND MotA RI. 1999. Estudo sobre a biologia do caranguejo-uçá, Ucides cordatus cordatus, (Linnaeus, 1763), capturado no delta do Rio Parnaíba, estado do Piauí. Bol Téc Cient CEPENE 7.

JARoEnSUTASINEE M AND JAROENSUTASINEE K. 2003. Male body size influences female choice and male-male competition in the fiddler crab Uca paradussumieri Bott, 1973 (Decapoda, Brachyura, Ocypodidae). Crustaceana 76: 177-186.

KEUNECKE KA, D'INCAO F AND FonseCA D. 2007. Growth and mortality of Hepatus pudibundus (Crustacea: Calappidae) in southwestern Brazil. J Mar Biol Assoc UK 87: 885-891.

KRISTENSEN E. 2008. Mangrove crabs as ecosystem engineers; with emphasis on sediment processes. J Sea Res 59: 30-43.

KyOMO J. 1988. Analysis of the relationship between gonads and hepatopancreas in males and females of the crab Sesarma intermedia, with reference to resource use and reproduction. Mar Biol 97: 87-93.

LEME MHA. 2002. A comparative analysis of the population biology of the mangrove crabs Aratus pisonii and Sesarma rectum (Brachyura, Grapsidae) from the north coast of São Paulo state, Brazil. J Crust Biol 22: 553-557.

Lima-Gomes RC, CoBo VJ And Fransozo A. 2011. Feeding Behavior and ecosystem role of the red mangrove crab Goniopsis cruentata (Latreille, 1803) (Decapoda, Grapsoidea) in a subtropical estuary on the Brazilian coast. Crustaceana 84: 735-747. 
LIRA JJPR, CALADO TCS AND ARAÚJO MSLC. 2012. Condition factor of Goniopsis cruentata (Crustacea, Brachyura, Grapsidae) from Mundaú/Manguaba estuarine complex, Alagoas, Brazil. Iheringia Sér Zool 102: 285-291.

LITULO C. 2005. Life history of the crab Macrophthalmus boscii (Audouin, 1826) (Decapoda, Brachyura, Ocypodidae). Crustaceana 78: 665-676.

LÓPEZ-GRECO LS AND RODRÍGUEZ EM. 1999. Annual reproduction and growth of adult crabs Chasmagnathus granulata (Crustacea, Brachyura, Grapsidae). Cah Biol Mar 40: 155-164.

Maciel DC AND Alves AGC. 2009. Local knowledge and practices related to Goniopsis cruentata (Latreille, 1803) in a coastal village in the State of Pernambuco, Northeast Brazil. Biota Neotrop 9: 29-36.

MANTElatto FLM AND Fransozo A. 1992. Relação peso/ largura da carapaça no caranguejo Hepatus pudibundus (Herbst, 1785) (Crustacea, Decapoda, Callapidae) na região de Ubatuba, SP, Brasil. Arq Biol Tecnol 35: 719-724.

MELLO JTC. 1973. Estudo populacional do camarão "rosa" Penaeus brasiliensis (Latreille, 1817) e Penaues paulensis (Perez-Farfante, 1967). Bol Inst Pesca 2: 19-65.

MElo GAS. 1996. Manual de Identificação dos Brackyura (caranguejos e siris) do litoral Brasileiro. São Paulo: Plêiade/Fapesp, 604 p.

MORGAN SG AND CHRISTY JH. 1995. Adaptive significance of the timing of larval release by crabs. Am Nat 145: 457-479.

Moura NFO, Coelho-Filho PA AND Coelho PA. 2000. Population structure of Goniopsis cruentata (Latreille, 1803 ) in the Paripe estuary, Brazil. Nauplius 8: 73-78.

MoURA NFO AND COELHO PA. 2003. Fecundidade de Goniopsis cruentata (Latreille, 1803) (Crustacea, Brachyura, Grapsidae) no manguezal do Rio Paripe - Pernambuco - Brasil. Trop Oceanogr 31: 127-133.

Moura NFO AND Coelho PA. 2004. Physiological sexual maturity of Goniopsis cruentata (Latreille) (Crustacea, Brachyura, Grapsidae) in the Paripe Estuary, Pernambuco State, Brazil. Rev Bras Zool 21: 1011-1015.

PAULY D. 1987. A review of the ELEPHAN system for analysis of length-frequency data in fish and aquatic invertebrates. In: Pauly D and Morgan GR (Eds), Length-based methods in fisheries research. Manila, Philippines: International Center for Living Aquatic Resources Management, p. 7-34.

Peiró DF, Pezzuto PR AND Mantelatto FL. 2011. Relative growth and sexual dimorphism of Austinixa aidae (Brachyura: Pinnotheridae): a symbiont of the ghost shrimp Callichirus major from the southwestern Atlantic. Lat Am J Aquat Res 39: 261-270.

PILLAY KK AND NAIR NB. 1971. The annual reproductive cycle of Uca annulipes, Portunus pelagicus and Metapenaeus affinis (Decapoda: Crustacea) from the South-west coast of India. Mar Biol 11: 152-166.

PILLAY KK AND NAIR NB. 1973. Observations on the biochemical changes in gonads and other organs of $U c a$ annulipes, Portunus pelagicus and Metapenaeus affinis (Decapoda : Crustacea) during the reproductive cycle. Mar Biol 18: 167-198.
PIMENTA AM, BARUTOT RA, D'INCAO F AND FonsECA DB 2005. Growth of Armases rubripes (Rathbun, 1897) in the estuary of the Lagoa dos Patos, Southern Brazil. Nauplius 13: 183-189.

Pinheiro MAA, Fiscarelli AG AND Hattori GY. 2005. Growth of the mangrove crab Ucides cordatus (Brachyura, Ocypodidae). J Crust Biol 25: 293-301.

PINHEIRO MAA AND FRANSOZO A. 1993. Biometric relationship analysis of the wet weight by carapace width to the swimming crab Arenaeus cribarius (Lamarck, 1818) (Crustacea, Brachyura, Portunidae). Arq Biol Tecnol 36: 331-341.

PINHEIRO MAA AND FRANSOZO A. 1999. Reproductive behavior of the swimming crab Arenaeus cribrarius (Lamarck, 1818) (Crustacea, Brachyura, Portunidae) in captivity. Bull Mar Sci 64: 243-253.

PINHEIRO MAA AND HATTORI GY. 2006. Growth of the speckled swimming crab, Arenaeus cribrarius (Lamarck, 1818) (Crustacea, Brachyura, Portunidae), in Ubatuba (SP), Brazil. J Nat Hist 40: 1331-1341.

PINHEIRO MAA AND TADDEI FG. 2005a. Crescimento do caranguejo de água doce, Dilocarcinus pagei Stimpson (Crustacea, Brachyura, Trichodactylidae). Rev Bras Zool 22: 522-528.

PINHEIRO MAA AND TADDEI FG. 2005b. Relação peso/ largura da carapaça e fator de condição em Dilocarcinus pagei Stimpson (Crustacea, Trichodactylidae), em São José do Rio Preto, São Paulo, Brasil. Rev Bras Zool 22: 825-829.

RAMIREZ LLODRA E. 2002. Fecundity and life-history strategies in marine invertebrates. Adv Mar Biol 43: 87-170.

Rosa RA AND NunES ML. 2002. Biochemical changes during the reproductive cycle of the deep-sea decapod Nephrops norvegicus on the south coast of Portugal. Mar Biol 141: 1001-1009.

RosA RA AND NUNES ML. 2003. Changes in organ indices and lipid dynamics during the reproductive cycle of Aristeus antennatus, Parapenaeus longirostris and Nephrops norvegicus (Crustacea: Decapoda) females from the south Portuguese coast. Crustaceana 75: 1095-1105.

SANTOS EP. 1978. Dinâmica de populações aplicada à pesca e piscicultura. São Paulo: Hucitec/ EDUSP, 129 p.

SANTOS MCF AND Botelho ERO. 2002. Estudos biológicos do aratu, Goniopsis cruentata (Latreille, 1803) (Crustacea: Decapoda: Grapsidae) no estuário do rio Una, município de São José da Coroa Grande (Pernambuco - Brasil). Bol Téc Cient CEPENE 10.

SANTOS MCF, ENGELFTEIN M AND GABRIELli MA. 1985. Relationships concerning respiratory devices in crabs from different habitats. Comp Biochem Physiol 81A: 567-570.

SASTRY AN. 1983. Ecological aspects of reproduction. In: Vernberg WB and Vernberg FJ (Eds), The biology of Crustacea, 8, Environmental adaptations. New York: Academic Press, p. 179-270.

SCHÖNE H. 1968. Agonistic and sexual display in aquatic and semi-terrestrial brachyuran crabs. Am Zool 8: 641-654. 
SCHÖNE H AND SCHÖNE H. 1963. Balz und andere Verhaltensweisen der Mangrovenkrabbe Goniopsis cruentata Latr. und das Winkverhalten der eulitoralen Brachyuren. Z Tierpsychol 20: 642-656.

Silva-Castiglioni D, Silva-CAstiglioni D AND NeGreirosFRANSOZO ML. 2004. Somatic growth of the mudflat fiddler crab Uca rapax (Smith, 1870) (Brachyura: Ocypodidae) from two subtropical mangroves in Brazil. Universidad Y Ciencia 20: 15-22.

SiLva Z AND OSHIRO LMY. 2002a. Growth in Goniopsis cruentata (Latreille) (Crustacea, Brachyura, Grapsidae) in laboratory. Rev Bras Zool 19: 915-923.

SILVA Z AND OSHIRO LMY. 2002b. Reproductive aspects of Goniopsis cruentata (Latreille) (Crustacea, Brachyura, Grapsidae) at the Sepetiba Bay, Rio de Janeiro, Brazil. Rev Bras Zool 19: 907-914.

SouZA LP AND SILVA JRF. 2009. Morphology of the female reproductive system of the red-clawed mangrove tree crab (Goniopsis cruentata Latreille, 1803). Sci Mar 73: 527-539.

SPAARGAREN DH AND HAEFNER Jr PA. 1994. Interactions of ovary and hepatopancreas during the reproductive cycle of Crangon crangon (L.). II. Biochemical Relationship. J Crust Biol 14: 6-19.

TADDEI FG AND HerRera DR. 2010. Growth of the crab Dilocarcinus pagei Stimpson, 1861 (Crustacea, Brachyura, Trichodactylidae) in the Barra Mansa Dam, mendonça, SP. Bol Inst Pesca 36: 99-110.
TAYLOR CC. 1958. Cod growth and temperatura. J Cons Int Explor Mer 23: 366-370.

TSUKIMURA B. 2001. Crustacean Vitellogenesis: Its Role in Oocyte Development. Amer Zool 41: 465-476.

TUCK ID, TAYLOR AC AND ATKINSON RJA. 1997. Biochemical composition of Nephrops norvegicus: changes associated with ovary maturation. Mar Biol 129: 505-511.

VALENTI WC, MELlo JTC AND LoBÃo VL. 1987. Crescimento de Macrobrachium acanthurus (Wiegmann 1836) do Rio Ribeira de Iguape (Crustacea, Decapoda, Palaemonidae). Rev Bras Biol 47: 349-355.

VASCONCELOS EMS, VASCONCELOS JA AND IVO CTC. 1999. Estudo sobre a biologia do caranguejo-uçá, Ucides cordatus cordatus, (Linnaeus, 1763), capturado no estuário do Rio Curimatau (Canguaretama - Rio Grande Do Norte). Bol Téc Cient CEPENE 7.

VAZzoler AEAM. 1981. Manual de métodos para estudos biológicos de populações de peixes. Reprodução e crescimento. Brasília: CNPq - Programa Nacional de Zoologia, 108 p.

VAZZOLER AEAM. 1996. Biologia da reprodução de peixes teleósteos: teoria e prática. Maringá: EDUEM, 196 p.

WERRY J AND LEE SY. 2005. Grapsid crabs mediate link between mangrove litter production and estuarine planktonic food chains. Mar Ecol Prog Ser 293: 165-176.

ZAR JH. 2010. Biostatistical Analysis, $5^{\text {th }}$ ed. Upper Saddle River, New Jersey: Pearson Prentice-Hall, 944 p. 
